\title{
The fibroblast growth factor 8 family in the female reproductive tract
}

\author{
Anthony Estienne and Christopher A Price \\ Centre de Recherche en Reproduction et Fertilité, Faculty of Veterinary Medicine, University of Montreal, \\ St-Hyacinthe, Quebec, Canada \\ Correspondence should be addressed to C Price; Email: christopher.price@umontreal.ca
}

\begin{abstract}
Several growth factor families have been shown to be involved in the function of the female reproductive tract. One subfamily of the fibroblast growth factor (FGF) superfamily, namely the FGF8 subfamily (including FGF17 and FGF18), has become important as Fgf8 has been described as an oocyte-derived factor essential for glycolysis in mouse cumulus cells and aberrant expression of FGF18 has been described in ovarian and endometrial cancers. In this review, we describe the pattern of expression of these factors in normal ovaries and uteri in rodents, ruminants and humans, as well as the expression of their receptors and intracellular negative feedback regulators. Expression of these molecules in gynaecological cancers is also reviewed. The role of FGF8 and FGF18 in ovarian and uterine function is described, and potential differences between rodents and ruminants have been highlighted especially with respect to FGF18 signalling within the ovarian follicle. Finally, we identify major questions about the reproductive biology of FGFs that remain to be answered, including (1) the physiological concentrations within the ovary and uterus, (2) which cell types within the endometrial stroma and theca layer express FGFs and (3) which receptors are activated by FGF8 subfamily members in reproductive tissues.

Reproduction (2018) 155 R53-R62
\end{abstract}

\section{Introduction}

Among the various growth factor families, the FGF family is one of the largest families with significant expression profiles in the female reproductive tract and with potentially important roles to play in fertility. This family is composed of 18 secreted proteins that are grouped into subfamilies according to sequence homology (Itoh \& Ornitz 2004), and members of each subfamily have similar receptor-binding characteristics. There are four tyrosine kinase FGF receptor (FGFR) genes, FGFR1, FGFR2, FGFR3 and FGFR4, and alternative splicing gives rise to two variants of FGFR1, FGFR2 and FGFR3 proteins, commonly termed the ' $b$ ' and ' $c$ ' forms. These variants have markedly different ligand-binding properties (Zhang et al. 2006), which confers specificity for certain FGF ligands. In general, the ' $b$ ' splice variants are expressed in mesenchymal cells and the ' $C$ ' splice forms are expressed in epithelial cells, allowing for precise paracrine signalling between ligand-receptor pairs. The role of mesenchymal-epithelial signalling by FGFs in the ovarian follicle has previously been discussed (Price 2016).

Various FGFs are best known for their role in branching morphogenesis and cell proliferation, and their general biology and pathology have been detailed in several excellent reviews (Beenken \& Mohammadi 2009,
Ornitz \& Itoh 2015). Mice null for many members of the FGF superfamily die in utero or perinatally, which illustrates the critical role of these growth factors in embryogenesis (Ornitz \& Itoh 2015). The impact of certain FGFs in adult tissue function is being appreciated, and they appear to be important for processes involving active tissue proliferation or regeneration, such as tumour development, wound repair, hair growth and ovarian follicle growth. The roles of a number of FGFs in the ovary has been reviewed (Chaves et al. 2012). The purpose of this review is to collate the available information about one specific subfamily of FGFs, the FGF8 subfamily and their receptors, in the female reproductive tract, with a focus on normal adult tissues, in order to highlight and discuss gaps in our understanding of these proteins.

\section{The FGF8 subfamily}

The FGF8 subfamily is of particular interest for reproductive biology and medicine. Indeed, the prototype ligand, FGF8, was first identified as an androgeninduced growth factor (its original name) secreted from a mammary carcinoma cell line (Tanaka et al. 1992). It has since been described in a number of breast and prostate cancer models (reviewed in Mattila \& Härkönen 2007) and in ovarian tumours (Valve et al. 2000). The other two members of the mammalian FGF8 subfamily are 
FGF17 and FGF18, and they have also been detected in prostate and breast cancer, respectively (Heer et al. 2004, Polnaszek et al. 2004, Mustacchi et al. 2013). The FGF8 subfamily is sometimes referred to as a synexpression group, and although there are examples of where all three are expressed in the same tissue such as endothelial cells (Antoine et al. 2005, Chui et al. 2014), there are numerous examples where one or two members are not expressed; for example, Fgf18 mRNA is abundant in adult mouse skin, whereas Fgf8 and Fgf17 mRNAs are essentially absent (Kawano et al. 2005).

The FGF8 subfamily arose from a common ancestor found in early vertebrates around 550 million years ago (Popovici et al. 2005). The amino acid sequences of FGF8, FGF17 and FGF18 are highly conserved across species; there is $98 \%$ homology among humans, mice and cattle for FGF8 and FGF18, and between mouse and human for FGF17 although the currently available bovine FGF17 sequence differs somewhat from these two previous species ( $73 \%$ homology). Within species, there is approximately $60 \%$ homology between FGF8, FGF17 and FGF18. Fish and lower orders express a fourth member of the FGF8 family, Fgf24, but this gene was lost in the tetrapod lineage about 400 million years ago (Jovelin et al. 2010). The FGF17 gene has been lost in frogs, fish and certain orders of birds including the chicken (Abramyan 2015). Owing to the importance of FGF8 and FGF18 in embryogenesis, it is not surprising that global knockout of Fgf8 and of Fgf18 causes embryonic or perinatal death in mice; Fgf17 appears to be less important as null mice survive (although they have impaired brain development) (reviewed in Ornitz \& Itoh 2015).

The FGF8 subfamily has very similar receptor-binding properties, as they activate the ' $C$ ' splice variants of FGFR1-3 and the non-spliced FGFR4. In addition, FGF8 undergoes alternative splicing to give rise to two main forms of biological relevance, FGF8a and FGF8b (Crossley \& Martin 1995). In studies with a BaF3 cell line expressing specific FGFR splice variants, human recombinant FGF8b, FGF17 and FGF18 efficiently activated FGFR3C and FGFR4; the FGF8 subfamily members do not activate FGFR2c and FGFR1c to the same degree (Table 1) (Zhang et al. 2006). FGF8a appears to have only weak binding affinity to FGFRs (MacArthur et al. 1995a, Olsen et al. 2006).

Table 1 Relative receptor activating abilities of FGF8 subfamilies expressed relative to FGF1.

\begin{tabular}{lcccc}
\hline & FGFR1c & FGFR2c & FGFR3c & FGFR4 \\
\hline FGF8b & +++ & +++ & ++++ & ++++ \\
FGF17 & + & + & ++++ & +++ \\
FGF18 & - & + & +++ & ++ \\
\hline
\end{tabular}

Data derived from Zhang et al. (2006).

++++ , more active than FGF1; +++; $51-100 \%$ activity of FGF1;

,$++ 30-50 \%$ activity of FGF $1 ;+, 5-29 \%$ activity of FGF1;

,$-<5 \%$ activity of FGF1.
Upon ligand binding, the intracellular tyrosine kinase domains of the receptors are phosphorylated and lead to activation of several intracellular signalling pathways including mitogen-activated protein kinase (MAPK), phospholipase C/protein kinase C, PI3K-AKT and signal transducer and activator of transcription (STAT), as has been extensively reviewed elsewhere (Ornitz \& Itoh 2015). These typical pathways have been described in the reproductive system and various FGFs have been shown to stimulate MAPK, AKT and PKC pathways in granulosa cells (Peluso et al. 2001, Jiang et al. 2011).

These pathways converge in the nucleus to induce the expression of transcription factors including FOS and members of the NR4A, ETS and EGR families (Kwong et al. 2001, Lammi \& Aarnisalo 2008, Jiang et al. 2013). Other FGF-response genes include negative feedback regulators of RTK activity, including members of the Sprouty (SPRY) family and interleukin 17 receptor D (IL17RD; also known as 'similar expression to FGF' SEF). These proteins act at different points along the MAPK signalling pathway (Ornitz \& Itoh 2015).

\section{Expression of FGF8 family in the ovary}

\section{Ligands}

In the adult mouse, mRNA encoding Fgf8 was initially detected only in the testis and ovary by Northern blot (Lorenzi et al. 1995, MacArthur et al. 1995b), but has subsequently been detected in human prostate, kidney, heart and lung by PCR (Ghosh et al. 1996, Schmitt et al. 1996), in human and mouse cerebral cortex, human skin and intestine by immunohistochemistry (IHC) (Tanaka et al. 2001, Zammit et al. 2002) and in blood vessels by PCR (Antoine et al. 2005). Within the ovary, Fgf8 mRNA was localised to the oocyte in mice by in situ hybridization (Valve et al. 1997) and PCR (Zhong et al. 2006), whereas mRNA levels appear low in oocytes, granulosa and theca cells in cattle (Buratini et al. 2005) and undetectable in normal human ovary (Valve et al. 2000). FGF8 protein has also been detected in human corpus luteum by IHC (Zammit et al. 2002).

Messenger RNA encoding FGF17 was detected in pooled mouse oocytes and in bovine oocytes by PCR (Zhong et al. 2006, Machado et al. 2009), although this gene appears to be weakly expressed: microarray data suggest that Fgf17 mRNA abundance is close to background levels in mice (Zhong et al. 2006) and TaqMan probes failed to detect FGF17 mRNA in single bovine oocytes (Ferreira et al. 2016). FGF17 mRNA was also detected in bovine theca and granulosa cells but at levels lower than those seen in oocytes, and FGF17 protein was detected in oocytes and granulosa cells (Machado et al. 2009). Owing to the low level of expression of this gene in the ovary, the physiological relevance of this growth factor is unclear, and it may be dispensable in mammals as it is in birds. 
Fgf18 mRNA was reported as one of the more highly expressed FGFs in mouse oocytes (Zhong et al. 2006) but curiously it was not detected in bovine oocytes; instead, FGF18 mRNA was detected primarily in theca cells (Portela et al. 2010). FGF18 protein was detected by $\mathrm{IHC}$ in bovine theca, granulosa and luteal cells (Portela et al. 2010). A major caveat to IHC and immunoblot studies is the potential for antibodies to cross-react with other FGF8 subfamily members; unfortunately, such cross-reactivity data are not always provided by manufacturers and reactivity with species such as cattle is often predicted.

Thus, the available data suggest species differences in the pattern of expression of FGF8 subfamily members; there is convincing evidence for Fgf8b expression in mice but not so for cattle and humans and that FGF18 is an oocyte-derived factor in mice but of thecal origin in cattle. Studies of other species are required to understand better the diversity of expression patterns within the ovary.

\section{Receptors}

All four FGF receptor mRNAs have been detected in the ovary. Early studies using Northern blotting and in situ hybridization detected Fgfr 1 and Fgfr2 mRNAs in rat theca and granulosa cells, and Fgfr 1 in the corpus luteum, whereas Fgfr 3 and Fgfr 4 mRNAs were not detected (Asakai et al. 1994). Fgfr3 mRNA was also not detected by in situ hybridization in the mouse ovary (Puscheck et al. 1997), which suggests generally lower abundance of FGFR3 compared to FGFR1 and FGFR2. More recent PCR experiments demonstrated the presence of FGFR3 mRNA in rat, mouse and human ovaries (Ben-Haroush et al. 2005, Drummond et al. 2007, Furukawa et al. 2014). Fgfr2 protein was detected in theca, granulosa and luteal cells as well as in oocytes in rats, whereas Fgfr3 protein was localized to the nucleus of granulosa cells (Drummond et al. 2007). FGFR1 and FGFR2 mRNAs and protein were detected in the parenchyma and vasculature of the sheep corpus luteum (Doraiswamy et al. 1998).

In mice, Fgfr4 mRNA was detected in granulosa cells by in situ hybridization (Puscheck et al. 1997) and in human ovarian biopsy samples by PCR (Valve et al. 2000, Ben-Haroush et al. 2005). FGFR4 mRNA was also detected in bovine theca cells and in buffalo granulosa and theca cells by PCR (Buratini et al. 2005, Mishra et al. 2016).

Splice variant-specific PCR demonstrated the presence of FGFR1C, FGFR2C and FGFR3C mRNAs in granulosa and theca cells of cattle (Berisha et al. 2004, Buratini et al. 2005, Mishra et al. 2016) and of FGFR1C and FGFR2C mRNAs in pig granulosa and theca cells (Schams et al. 2009, Evans et al. 2014, Furukawa et al. 2014). In human ovarian samples, FGFR1C and FGFR2C mRNAs were detected but FGFR3C mRNA was not
(Valve et al. 2000), whereas all 'C' splice forms and FGFR4 mRNA was detected in commercially available human ovarian RNA (Cole et al. 2010). The abundance of FGFR mRNAs change with follicle development, for example, the abundance of FGFR2C mRNA in granulosa cells is highest in large compared to small follicles in pigs and buffalo (Evans et al. 2014, Mishra et al. 2016). A similar pattern has been described in theca cells in pigs (Schams et al. 2009), whereas no difference was noted in cattle (Berisha et al. 2004). Granulosa cell FGFR3C and FGFR4 mRNA levels were highest in large follicles in cattle (Buratini et al. 2005) and buffalo (Mishra et al. 2016), respectively, compared with smaller follicles.

The previously mentioned data should be viewed with caution, as PCR studies of receptors and their splice variants give little indication of relative abundance of active receptor proteins on the cell surface. Unfortunately, some reports do not provide $\mathrm{Cq}$ values of target amplicons and some persist in measuring non-splice variant-specific targets. Work in this area is also hampered by the lack of splice-variantspecific antibodies.

\section{Regulators}

Of the Sprouty proteins, SPRY 2 mRNA was first detected in bovine granulosa cells (Robert et al. 2001) and subsequently detected in human granulosa-lutein cells and mouse cumulus cells (Haimov-Kochman et al. 2005, Sugiura et al. 2009). Haimov-Kochman and coworkers localized SPRY2 protein to human granulosa-lutein cells by IHC but not to theca-lutein cells and to the stroma and granulosa cells of hCG-treated rats (HaimovKochman et al. 2005). Abundance of SPRY1, SPRY2 and SPRY4 mRNAs is increased by FGFs in bovine granulosa cells, including by FGF8 (Jiang et al. 2013); FGF18 appeared unable to stimulate SPRY mRNA levels. Messenger RNA encoding SPRY3 has been detected in bovine granulosa cells but is not stimulated by FGFs (Jiang et al. 2011, 2013).

IL17RD protein and mRNA has been detected in mouse and human follicles, where they are found mostly in cumulus/granulosa cells and the oocyte but absent in luteal cells. Interleukin 17 receptor D proteins were not detected in theca cells of mice, but were detected in theca cells of human ovaries (Lutwak et al. 2014); the strength and importance of this apparent species difference remains to be determined.

\section{Role of FGF8 subfamily in the ovary}

The role of FGF8 as an oocyte-somatic cell signalling molecule was suggested by studies in mice demonstrating that two oocyte-derived proteins, FGF8b and BMP15, synergize to promote glycolysis in cumulus cells (Sugiura et al. 2007). Addition of FGF8b to rat granulosa-oocyte cocultures inhibited $\mathrm{FSH}$-induced 
oestradiol secretion and increased MAPK3/1 and MAPK8 phosphorylation (Miyoshi et al. 2010). Similarly, FGF8b increased MAPK3/1 phosphorylation in bovine granulosa cells (Jiang et al. 2013).

Although little is known about the regulation of FGF8 expression or secretion from oocytes, $\mathrm{FSH}$ has been shown to increase Fgf8 mRNA levels from oocytes of cultured mouse follicles (Sánchez et al. 2010), whereas eCG priming in vivo decreased Fgf8 mRNA abundance (Sánchez et al. 2011). Kit ligand (Kitl) stimulated oocyte Fgf8 mRNA levels in rats (Miyoshi et al. 2012) and FGF8 was shown to increase KITL mRNA abundance in bovine cumulus cells (Lima et al. 2016), suggesting the presence of a feedforward loop between Fgf8 and Kitl. Interestingly, a $\mathrm{G} \rightarrow \mathrm{C}$ mutation in the bovine FGF8 gene has been associated with a reduction in the number of viable oocytes collected during ultrasoundguided ovum pick up in Nelore (Bos indicus) cows (Santos-Biase et al. 2012).

The effects of FGF17 and FGF18 on bovine granulosa cells have been reported, and both inhibit steroidogenesis (Machado et al. 2009, Portela et al. 2010). Addition of FGF17 to in vitro fertilization (IVF) medium enhanced cumulus expansion in cattle, and in combination with BMP15 increased the number of cells in the blastocyst inner cell mass (Machado et al. 2015). An atypical action of FGF1 8 was described, in that this ligand increased the proportion of apoptotic granulosa cells in vitro, possibly through a mechanism involving the intracellular death ligand BBC3 (also known as PUMA), and injection of FGF1 8 directly into a growing follicle in vivo resulted in atresia (Portela et al. 2010, 2015). While the potential signalling between oocytes and cumulus cells involving FGF8 may be common to rodents and ruminants, the involvement of theca-derived FGFs in rodents remains to be explored (Fig. 1).

\section{Expression and role of FGF8 subfamily in the uterus}

Within the uterus, FGF8 protein was detected in human endometrial glands and myometrium by IHC, although the endometrial stroma was negative, and in the oviductal epithelium (Zammit et al. 2002). FGF18 mRNA was also detected in human endometrium (Yerlikaya et al. 2016) and in the mouse uterine stroma (Li et al. 2011).

Limited information is available to date about FGFR expression in the human uterus, although all FGFRs were detected in the placenta but not in the maternal decidua (Anteby et al. 2005). FGFR2 protein was subsequently detected predominantly in the human endometrial epithelium of the secretory phase and in trace amounts in the proliferative endometrium (Gatius et al. 2011) and FGFR1 and FGFR2 proteins were localized to the uterine epithelium in mice (Li et al. 2011). In pigs, the endometrium expresses FGFR1C and FGFR2C mRNAs, the latter in greater concentrations that the former, and

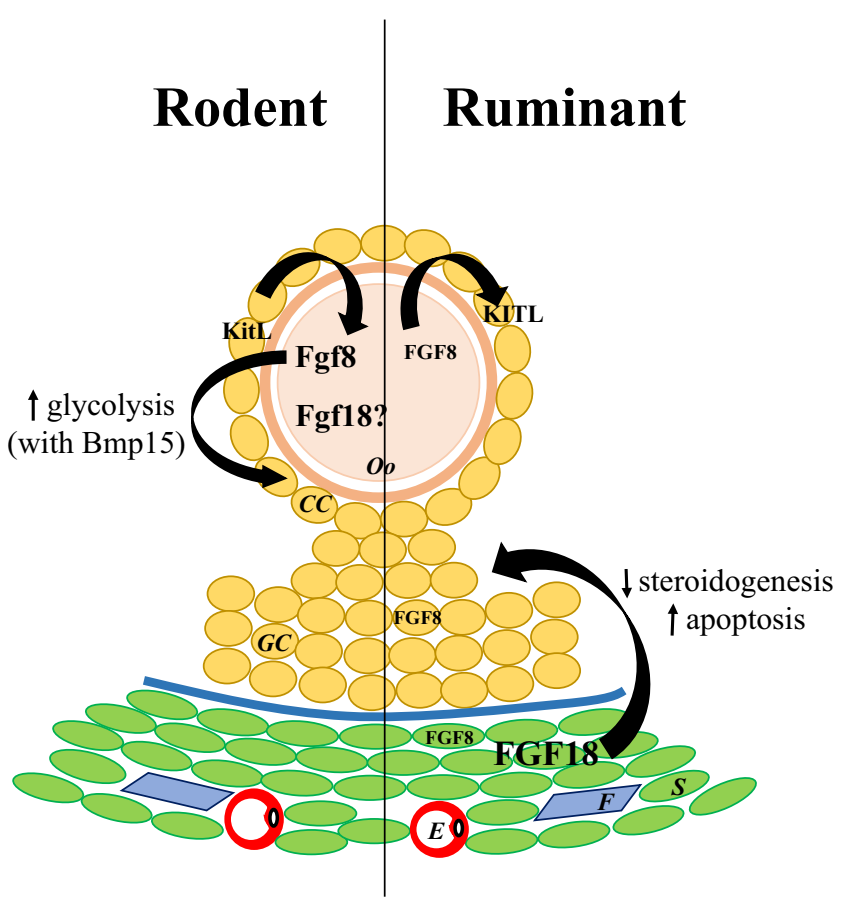

Figure 1 Model for the action of FGF8 subfamily members in the ovarian follicle. In both rodents and ruminants, FGF8 is expressed by (at least) the oocyte $(\mathrm{Oo})$ and has been shown to stimulate KITL mRNA levels in bovine cumulus cells, and KitL stimulated Fgf8 mRNA in rodents; a feedforward loop likely exists between these two factors. Cumulus cell glycolysis is stimulated by Fgf8 and Bmp15 in mice, which has not yet been demonstrated in other species. In cattle, FGF18 is predominantly expressed by the theca cell layer and increases apoptosis in granulosa cells $(G C)$. It is not clear whether FGF18 is secreted from thecal steroidogenic cells $(S)$, fibroblasts $(F)$ or endothelial cells $(E)$, or whether Fgf18 is expressed in rodent theca cells. Size of growth factor letters indicates approximate level of abundance.

FGFR2C mRNA levels were decreased by progesterone or oestradiol administration (Welter et al. 2004). Several FGFs are expressed by the ruminant endometrium, as well as FGFR2C (Okumu et al. 2014), although most studies have focused on FGF10 that signals to the conceptus, which expresses FGFRs (Chen et al. 2000, Ocón-Grove et al. 2008). Progesterone stimulated endometrial FGF10 expression in sheep but not in cattle (Satterfield et al. 2008, Okumu et al. 2014); to date, no data are available on endometrial FGF8 subfamily members in ruminants.

FGF signalling has been implicated in the control of uterine epithelial proliferation, as pharmacological inhibition of FGFR activity decreases proliferative activity in mice (Nallasamy et al. 2012). In order for implantation to occur, epithelial proliferation ceases under the control of a progesterone-induced basic helix-loop-helix transcription factor, Hand2, and loss of Hand2 increased the expression of several FGFs in the mouse uterus including Fgf18 (Li et al. 2011). Another transcription factor, Msx1, is also critical for implantation 


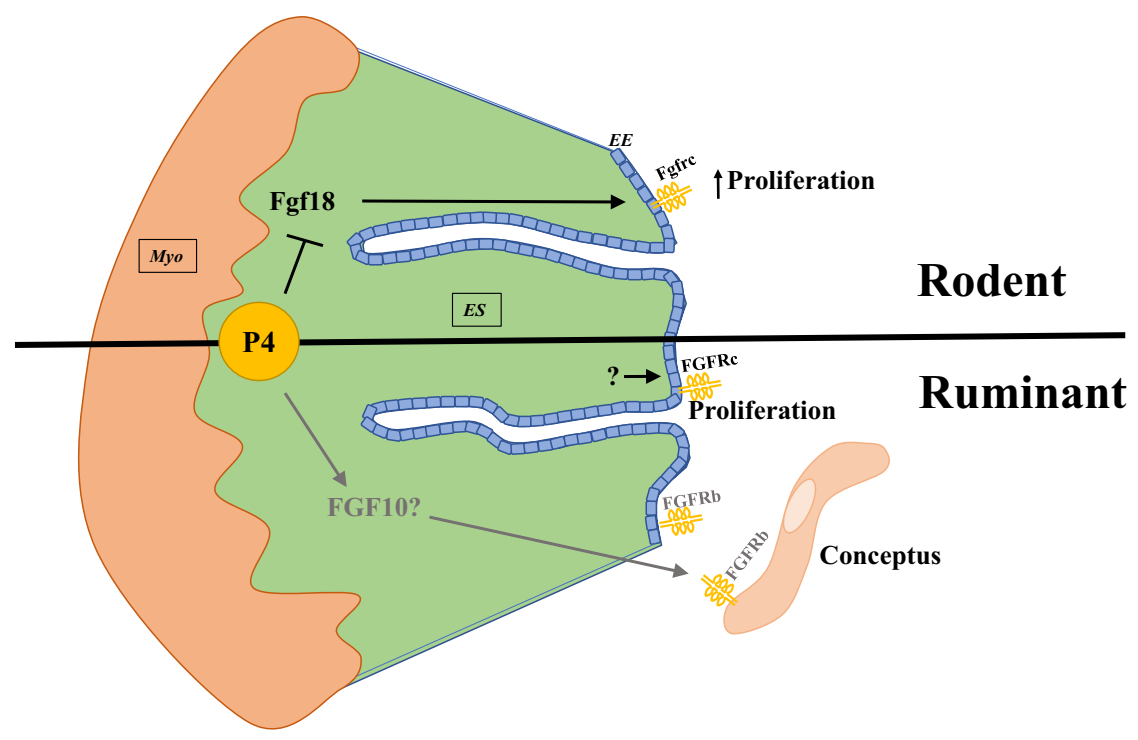

Figure 2 Current (mis)understanding of FGF8 family signalling in the uterus. Evidence suggests that in mice Fgf18 is secreted by the endometrial stroma $(E S)$ and activates ' $\mathrm{C}$ ' splice variants of Fgfr on the epithelium (EE) to promote proliferation and that this pathway is suppressed by progesterone to allow implantation. In ruminants (and other species), although it is believed that FGF10 activates the ' $b$ ' splice variants on the epithelium and the conceptus to facilitate implantation (grey text and lines), it is not yet known if FGF8 family members activate epithelial ' $\mathrm{C}$ ' receptors to regulate proliferation. $M y_{0}$, myometrium.

in mice, and loss of Msx1 increased the expression of Fgf18 and Fgf10 among others (Nallasamy et al. 2012). Thus, in mice, the data suggest that progesterone signalling, through Hand2 and potentially other factors such as Msx1, inhibits FGF expression in the uterine stroma leading to a reduction in FGF signalling to the uterine epithelium, which in turn reduces proliferation and allows the endometrium to become receptive to implantation. A hypothetical model of FGF8 subfamily signalling in rodents and ruminants is given in Fig. 2.

The negative RTK regulator SPRY2 has been detected in human endometrial glands by $\mathrm{IHC}$, and its abundance is higher in the secretory compared with the proliferative endometrium (Velasco et al. 2011). In humans, SPRY4 and IL17RD proteins have been located to the endometrial epithelium without cyclical changes (Guo et al. 2014).

\section{Gynaecological cancers}

FGF8 mRNA and protein were detected in ovarian tumours and cancer cell lines by PCR and IHC (Valve et al. 2000). Levels of FGF18 protein have been proposed as a marker for poor prognosis of ovarian tumours (Wei et al. 2013, El-Gendi et al. 2016), and serum FGF18 protein concentrations were higher in postmenopausal ovarian cancer patients compared with healthy postmenopausal controls (Vathipadiekal et al. 2015). Moreover, a polymorphism in the $5^{\prime}$ flanking region of FGF18 was associated with improved response to platinum-based chemotherapy (Meng et al. 2013).

In endometrial cancer, abundance of FGF18 mRNA was elevated and HAND2 mRNA levels were decreased in endometrial adenocarcinomas compared to normal human proliferative endometria (Flannery et al. 2016). There is little evidence to date to suggest aberrant expression of FGF8 or FGF17 in endometrial cancers.
Alterations in FGFR gene structure and signalling have been associated with gynaecological cancers and have been reviewed elsewhere (Fearon et al. 2013); attention will be paid here only to events involving the FGF8 subfamily. Endometrial carcinoma has been associated with mutations that occur in FGFR2 (Pollock et al. 2007, Gatius et al. 2011), and a particularly prevalent mutation, Ser252Trp, alters ligand specificity of the receptor such that mutated FGFR2c is activated by FGFs that normally activate only ' $b$ ' splice variants (FGF7 and FGF10). Another study demonstrated that mutated FGFR2 $b$ is activated by ligands that normally activate the ' $\mathrm{c}$ ' splice variants (Yu et al. 2000); therefore, it can be expected that FGF8 subfamily members may be able to activate the mutated FGFR2b, although this has not been tested.

Some ovarian cancers are believed to arise from the surface epithelium, which expresses the epithelial ' $b$ ' splice variants of the FGFRs (Steele et al. 2001), and these splice forms of FGFR2 and FGFR3 are the predominant forms in ovarian cancer, along with FGFR1c (Cole et al. 2010). Ovarian cancer likely also arises from the oviduct (Kim et al. 2012), and limited information available suggests that the ' $c$ ' splice forms are expressed in the oviductal epithelium, at least in pigs (Wollenhaupt et al. 2004). Although FGFR2 mutations are considered rare in ovarian cancer, the Ser252Trp mutation seen in endometrial cancer has also been detected in the ovary (Byron et al. 2010), suggesting a loss of ligand specificity for FGF signalling in at least some ovarian cancers.

High levels of FGFR4 protein have been reported in serous ovarian carcinomas and were associated with poor patient survival (Zaid et al. 2013), although the ligand involved was suggested to be FGF19 (Hu \& Cong 2015). On the other hand, a Gly388Arg mutation in FGFR4 has been reported in ovarian cancer and was associated with increased patient survival (Marmé et al. 2012). 
In concert with the increase in FGF ligand expression in cancer, there is a decrease in expression of negative feedback regulators of RTK activity. Indeed, SPRY1, SPRY2, SPRY4 and IL17RD mRNA levels were reported to be generally lower in ovarian tumours compared with normal human ovarian tissue (Zisman-Rozen et al. 2007, Masoumi-Moghaddam et al. 2015a,b). It seems likely that if FGF8 and FGF18 are major contributors to aberrant FGFR activity in cancer, the loss of endogenous negative feedback to the MAPK signalling cascade could exacerbate the oncogenic effects of FGFs within the female reproductive tract. It is perplexing that FGF18 is associated with tumour growth but is proapoptotic in non-cancerous granulosa cells. This may be because of altered receptor specificity or aberrant expression of co-factors or downstream regulators/pathways in tumours, and the causal relationship between FGF18 synthesis and tumour development has not been determined.

\section{FGF8 signalling and microRNAs}

MicroRNAs haveemerged as regulators of geneexpression and cell signalling, and although specific examples of FGF-microRNA interactions in the reproductive system have not been reported, interactions have been reported during morphogenesis of other organ systems. As an example, miR-130 and miR-133 have been shown to inhibit Fgf8 mRNA levels in the embryonic chick heart (Lopez-Sanchez et al. 2015a,b), potentially by altering signalling through Fgfr1. In zebrafish, miR-9 inhibits FGF signalling in the developing brain and does so by binding directly to the 3'UTR of Fgf8 mRNA (Leucht et al. 2008). In human endothelial cells, hsamiR-505 inhibited FGF18 mRNA and protein levels and inhibited the activity of a luciferase reporter containing the 3'UTR of FGF18 (Yang et al. 2014) suggesting that this microRNA interacts directly with FGF18 mRNA. Another miRNA that interacts with the 3'UTR of FGF18 is miR-195 (Wang et al. 2017). Whether these miRNAs are involved in reproductive physiology or medicine is just being explored, although miR-505 abundance was found to be downregulated in endometrial carcinoma (Chen et al. 2016), a tissue in which increased FGF18 mRNA levels have been observed (see section on 'Gynaecological cancers'.).

\section{Questions and challenges}

There are many unresolved questions about the physiological role of FGFs in the reproductive as well as other organ systems. One fundamental question concerns the physiologically relevant concentrations of FGFs in biological fluids and tissues. Unlike the FGF19 subfamily, which are endocrine factors and secreted into the bloodstream, many other FGFs are paracrine factors and remain closely associated with the extracellular matrix. Most is known about FGF2, which is exported to the cell surface and is not readily released into culture medium (Trudel et al. 2000); nevertheless, concentrations of FGF2 in human serum and follicular fluid (FF) have been reported to be 5-10 and $100-150 \mathrm{pg} / \mathrm{mL}$, respectively (Hammadeh et al. 2003). Although some studies have reported biological effects of FGF2 on granulosa cells at $100 \mathrm{pg} / \mathrm{mL}$ (Vernon \& Spicer 1994), most studies use doses of $\geq 1000 \mathrm{pg} / \mathrm{mL}$ (for example, Jiang et al. 2011), therefore determining the peri-cellular concentrations is important to establish whether experimental doses of FGF2 are physiologically relevant. The same reasoning applies to FGF18, for which the plasma FGF18 concentrations in healthy humans are around $160 \mathrm{pg} / \mathrm{mL}$ (Dr Michael Grusch, Medical University of Vienna, personal communication). If the plasma:FF ratio of 1:10 observed for FGF2 is valid also for FGF18, one can predict levels of $1.6 \mathrm{ng} / \mathrm{mL}$ in FF, which are 5 -fold lower than concentrations used in most studies on the effects of FGF18.

Precise cell localization in non-epithelial cell compartments remains to be clarified. Endometrial stroma and the follicular theca layer contain many mesenchymal cell types and the contribution of each to FGF production is not clear. Specifically, FGF18 is possibly produced by fibroblasts or endothelial cells within the endometrial stroma as it has been detected in these cell types of other tissues (Kapoun et al. 2004, Antoine et al. 2005). This may also hold for the theca cell layer, as expression has not, to our knowledge, been demonstrated in steroidogenic cells. It should also be noted that in human umbilical vein endothelial cell lines the expression of FGF18 is regulated by hsa-miR-505, as is the expression of high-mobility group box 1 (HMGB1) (Yang et al. 2014), and HMGB1 has been implicated in preeclampsia (Nadeau-Vallée et al. 2016). As FGF18 administration caused dilatation in the rat cerebral vasculature (Ellsworth et al. 2003), it would be worth investigating if FGF18 plays a role in preeclampsia.

A further critical question that remains largely unanswered concerns receptor presence and specificity. The landmark papers that identified which receptors are activated by specific ligands was performed with a mouse pre-B cell line $(\mathrm{BaF} 3)$ transfected with individual FGFRs (Ornitz et al. 1996, Zhang et al. 2006), but few attempts have been made to confirm that the same pattern of receptor activation occurs in primary cells. Measuring receptor abundance by PCR is also problematic, as mRNA abundance does not always reflect levels of active protein. As an example, human neutrophils express FGFR 1, FGFR2 and FGFR 4 mRNA but only FGFR2 protein exists as a transmembrane receptor - FGFR1 and FGFR4 proteins were localized to an intracellular compartment by confocal immunofluorescence (Haddad et al. 2011). In rat granulosa cells, Fgfr2 protein was localised to the cytoplasm by IHC, and therefore, potentially at the cell surface, whereas Fgfr3 protein was restricted to the 
nucleus (Drummond et al. 2007); whether this reflects receptors that have been internalized after activation or a non-functional form of receptor is unknown, but it should be remembered that Fgfr3 is not an abundant receptor in the ovary (see above). By using specific receptor-blocking antibodies, Fortin and coworkers demonstrated with rat oligodendrocytes that FGF8 does not activate FGFR1 (Fortin et al. 2005), whereas it does in BaF3 cells (Zhang et al. 2006). Thus, the extent to which a given FGF activates specific receptors may be dependent on cell context (cell type, species, stage of differentiation).

Finally, the question of potential species differences should be addressed. Minor differences in receptor splice variant mRNA levels may not be physiologically relevant but some other differences stand out. These include the robust expression of Fgf8b exclusively in mouse oocytes but weaker expression throughout the follicle in cattle, the localization of Fgf18 mRNA to the oocyte in mice but robust expression of FGF18 in theca cells of cattle and the expression of $/ 17 \mathrm{rd}$ mRNA in granulosa cells and oocytes of mice but in theca cells in humans. These patterns must be verified in a greater range of species before any conclusions can be drawn, but the glaring difference in ovulation rate between mice and humans/cattle suggest that FGFs may play a role in determining the number of follicles that develop to the preovulatory stage.

\section{Declaration of interest}

C A P is an Editor-in-Chief of Reproduction.

\section{Funding}

Work from the authors' laboratory included in this review has been funded by the Natural Sciences and Engineering Research Council of Canada (NSERC).

\section{References}

Abramyan J 2015 Lineage-specific loss of FGF17 within the avian orders galliformes and passeriformes. Gene 563 180-189. (https://doi. org/10.1016/j.gene.2015.03.027)

Anteby EY, Natanson-Yaron S, Hamani Y, Sciaki Y, Goldman-Wohl D, Greenfield C, Ariel I \& Yagel S 2005 Fibroblast growth factor-10 and fibroblast growth factor receptors 1-4: expression and peptide localization in human decidua and placenta. European Journal of Obstetrics and Gynecology and Reproductive Biology 119 27-35. (https://doi.org/10.1016/j.ejogrb.2004.05.014)

Antoine M, Wirz W, Tag CG, Mavituna M, Emans N, Korff T, Stoldt V, Gressner AM \& Kiefer P 2005 Expression pattern of fibroblast growth factors (FGFs), their receptors and antagonists in primary endothelial cells and vascular smooth muscle cells. Growth Factors 23 87-95. (https://doi.org/10.1080/08977190500096004)

Asakai R, Song SY, Itoh N, Yamakuni T, Tamura K \& Okamoto R 1994 Differential gene expression of fibroblast growth factor receptor isoforms in rat ovary. Molecular and Cellular Endocrinology 104 75-80. (https://doi.org/10.1016/0303-7207(94)90053-1)
Beenken A \& Mohammadi M 2009 The FGF family: biology, pathophysiology and therapy. Nature Reviews Drug Discovery 8 235-253. (https://doi. org/10.1038/nrd2792)

Ben-Haroush A, Abir R, Ao A, Jin S, Kessler-Icekson G, Feldberg D \& Fisch B 2005 Expression of basic fibroblast growth factor and its receptors in human ovarian follicles from adults and fetuses. Fertility and Sterility 84 (Supplement 2) 1257-1268. (https://doi.org/10.1016/j. fertnstert.2005.05.018)

Berisha B, Sinowatz F \& Schams D 2004 Expression and localization of fibroblast growth factor (FGF) family members during the final growth of bovine ovarian follicles. Molecular Reproduction and Development 67 162-171. (https://doi.org/10.1002/mrd.10386)

Buratini J Jr, Teixeira AB, Costa IB, Glapinski VF, Pinto MGL, Giometti IC, Barros CM, Cao M, Nicola ES \& Price CA 2005 Expression of fibroblast growth factor- 8 and regulation of cognate receptors, fibroblast growth factor receptor (FGFR)-3c and -4, in bovine antral follicles. Reproduction 130 343-350. (https://doi.org/10.1530/rep.1.00642)

Byron SA, Gartside MG, Wellens CL, Goodfellow PJ, Birrer MJ, Campbell IG \& Pollock PM 2010 FGFR2 mutations are rare across histologic subtypes of ovarian cancer. Gynecologic Oncology 117 125-129. (https://doi.org/10.1016/j.ygyno.2009.12.002)

Chaves RN, Tavares de Matos MH, Buratini J \& Ricardo de Figueiredo J 2012 The fibroblast growth factor family: involvement in the regulation of folliculogenesis. Reproduction, Fertility and Development $\mathbf{2 4}$ 905-915. (https://doi.org/10.1071/RD11318)

Chen C, Spencer TE \& Bazer FW 2000 Fibroblast growth factor-10: a stromal mediator of epithelial function in the ovine uterus. Biology of Reproduction 63 959-966. (https://doi.org/10.1095/biolreprod63.3.959)

Chen S, Sun K-X, Liu B-L, Zong Z-H \& Zhao Y 2016 MicroRNA-505 functions as a tumor suppressor in endometrial cancer by targeting TGF- $\alpha$. Molecular Cancer 15 11. (https://doi.org/10.1186/s12943-0160496-4)

Chui A, Murthi P, Gunatillake T, Brennecke SP, Ignjatovic V, Monagle PT, Whitelock JM \& Said JM 2014 Altered decorin leads to disrupted endothelial cell function: a possible mechanism in the pathogenesis of fetal growth restriction? Placenta 35 596-605. (https://doi.org/10.1016/j. placenta.2014.05.009)

Cole C, Lau S, Backen A, Clamp A, Rushton G, Dive C, Hodgkinson C, McVey R, Kitchener H \& Jayson GC 2010 Inhibition of FGFR2 and FGFR1 increases cisplatin sensitivity in ovarian cancer. Cancer Biology and Therapy 10 495-504. (https://doi.org/10.4161/cbt.10.5.12585)

Crossley PH \& Martin GR 1995 The mouse Fgf8 gene encodes a family of polypeptides and is expressed in regions that direct outgrowth and patterning in the developing embryo. Development 121 439-451.

Doraiswamy V, Knutson DL, Grazul-Bilska AT, Redmer DA \& Reynolds LP 1998 Fibroblast growth factor receptor (FGFR)-1 and -2 in the ovine corpus luteum throughout the estrous cycle. Growth Factors 16 125-135. (https://doi.org/10.3109/08977199809002123)

Drummond AE, Tellbach M, Dyson M \& Findlay JK 2007 Fibroblast growth factor-9, a local regulator of ovarian function. Endocrinology 148 3711-3721. (https://doi.org/10.1210/en.2006-1668)

El-Gendi S, Abdelzaher E, Mostafa MF \& Sheasha GA 2016 FGF18 as a potential biomarker in serous and mucinous ovarian tumors. Tumor Biology 37 3173-3183. (https://doi.org/10.1007/s13277-015-4129-0)

Ellsworth JL, Garcia R, Yu J \& Kindy MS 2003 Fibroblast growth factor-18 reduced infarct volumes and behavioral deficits after transient occlusion of the middle cerebral artery in rats. Stroke 34 1507. (https://doi. org/10.1161/01.STR.0000071760.66720.5F)

Evans JR, Schreiber NB, Williams JA \& Spicer LJ 2014 Effects of fibroblast growth factor 9 on steroidogenesis and control of FGFR2IIIC mRNA in porcine granulosa cells12. Journal of Animal Science 92 511-519. (https://doi.org/10.2527/jas.2013-6989)

Fearon AE, Gould CR \& Grose RP 2013 FGFR signalling in women's cancers. International Journal of Biochemistry and Cell Biology 45 2832-2842. (https://doi.org/10.1016/j.biocel.2013.09.017)

Ferreira RM, Chiaratti MR, Macabelli CH, Rodrigues CA, Ferraz ML, Watanabe YF, Smith LC, Meirelles FV \& Baruselli PS 2016 The infertility of repeat-breeder cows during summer is associated with decreased mitochondrial DNA and increased expression of mitochondrial and apoptotic genes in oocytes. Biology of Reproduction 94 66. (https://doi. org/10.1095/biolreprod.115.133017) 
Flannery CA, Fleming AG, Choe GH, Naqvi H, Zhang M, Sharma A \& Taylor HS 2016 Endometrial cancer-associated FGF18 expression is reduced by bazedoxifene in human endometrial stromal cells in vitro and in murine endometrium. Endocrinology 157 3699-3708. (https://doi.org/10.1210/en.2016-1233)

Fortin D, Rom E, Sun H, Yayon A \& Bansal R 2005 Distinct fibroblast growth factor (FGF)/FGF receptor signaling pairs initiate diverse cellular responses in the oligodendrocyte lineage. Journal of Neuroscience $\mathbf{2 5}$ 7470. (https://doi.org/10.1523/JNEUROSCI.2120-05.2005)

Furukawa S, Matsuno Y, Emori C, Fujii W, Naito K \& Sugiura K 2014 Expression and regulation of FGF receptors in mouse granulosa cells. Journal of Mammalian Ova Research 31 86-92. (https://doi.org/10.1274/ jmor.31.86)

Gatius S, Velasco A, Azueta A, Santacana M, Pallares J, Valls J, Dolcet X, Prat J \& Matias-Guiu X 2011 FGFR2 alterations in endometrial carcinoma. Modern Pathology 24 1500-1510. (https://doi.org/10.1038/ modpathol.2011.110)

Ghosh A, Shankar D, Shackleford G, Wu K, T'Ang A, Miller G, Zheng J \& Roy-Burman P 1996 Molecular cloning and characterization of human FGF8 alternative messenger RNA forms. Cell Growth and Differentiation 7 1425-1434.

Guo Q, Zhang H, Zhao X, Fu Y, Zhang J \& Li M 2014 Loss of expressions of Dusp6, Sprouty4, and Sef, negative regulators of FGF2/ERK1/2 signaling, in the endometrium of women with adenomyosis. International Journal of Gynaecological Pathology 33 288-297. (https://doi.org/10.1097/ PGP.0b013e3182a54ab3)

Haddad LE, Khzam LB, Hajjar F, Merhi Y \& Sirois MG 2011 Characterization of FGF receptor expression in human neutrophils and their contribution to chemotaxis. American Journal of Physiology: Cell Physiology 301 C1036. (https://doi.org/10.1152/ajpcell.00215.2011)

Haimov-Kochman R, Ravhon A, Prus D, Greenfield C, Finci-Yeheskel Z, D SG-W, Natanson-Yaron S, Reich R, Yagel S \& Hurwitz A 2005 Expression and regulation of Sprouty-2 in the granulosa-lutein cells of the corpus luteum. Molecular Human Reproduction 11 537-542. (https://doi. org/10.1093/molehr/gah203)

Hammadeh ME, Fischer-Hammadeh C, Hoffmeister H, Huebner U, Georg T, Rosenbaum P \& Schmidt W 2003 Fibroblast growth factor (FGF), intracellular adhesion molecule (sICAM-1) level in serum and follicular fluid of infertile women with polycystic ovarian syndrome, endometriosis and tubal damage, and their effect on ICSI outcome. American Journal of Reproductive Immunology 50 124-130. (https://doi. org/10.1034/j.1600-0897.2003.00056.x)

Heer R, Douglas D, Mathers ME, Robson CN \& Leung HY 2004 Fibroblast growth factor 17 is over-expressed in human prostate cancer. Journal of Pathology 204 578-586. (https://doi.org/10.1002/path.1668)

Hu L \& Cong L 2015 Fibroblast growth factor 19 is correlated with an unfavorable prognosis and promotes progression by activating fibroblast growth factor receptor 4 in advanced-stage serous ovarian cancer. Oncology Reports 34 2683-2691. (https://doi.org/10.3892/ or.2015.4212)

Itoh N \& Ornitz DM 2004 Evolution of the Fgf and Fgfr gene families. Trends in Genetics 20 563-569. (https://doi.org/10.1016/j.tig.2004.08.007)

Jiang ZL, Ripamonte P, Buratini J, Portela VM \& Price CA 2011 Fibroblast growth factor-2 regulation of Sprouty and NR4A genes in bovine ovarian granulosa cells. Journal of Cellular Physiology 226 1820-1827. (https://doi.org/10.1002/jcp.22509)

Jiang Z, Guerrero-Netro HM, Juengel JL \& Price CA 2013 Divergence of intracellular signaling pathways and early response genes of two closely related fibroblast growth factors, FGF8 and FGF18, in bovine ovarian granulosa cells. Molecular and Cellular Endocrinology 375 97-105. (https://doi.org/10.1016/j.mce.2013.05.017)

Jovelin R, Yan YL, He X, Catchen J, Amores A, Canestro C, Yokoi H \& Postlethwait JH 2010 Evolution of developmental regulation in the vertebrate FgfD subfamily. Journal of Experimental Zoology Part B: Molecular and Developmental Evolution 314B 33-56. (https://doi. org/10.1002/jez.b.21307)

Kapoun AM, Liang F, O'Young G, Damm DL, Quon D, White RT, Munson K, Lam A, Schreiner GF \& Protter AA 2004 B-type natriuretic peptide exerts broad functional opposition to transforming growth factor $\beta$ in primary human cardiac fibroblasts. Circulation Research 94 453. (https://doi.org/10.1161/01.RES.0000117070.86556.9F)
Kawano M, Komi-Kuramochi A, Asada M, Suzuki M, Oki J, Jiang J \& Imamura T 2005 Comprehensive analysis of FGF and FGFR expression in skin: FGF18 is highly expressed in hair follicles and capable of inducing anagen from telogen stage hair follicles. Journal of Investigative Dermatology 124 877-885. (https://doi.org/10.1111/j.0022-202X.2005.23693.x)

Kim J, Coffey DM, Creighton CJ, Yu Z, Hawkins SM \& Matzuk MM 2012 High-grade serous ovarian cancer arises from fallopian tube in a mouse model. PNAS 109 3921-3926. (https://doi.org/10.1073/ pnas.1117135109)

Kwong WH, Tang MK, Yew DT, Chan JY, Cai DQ, Tong WM \& Lee KK 2001 Fibroblast growth factor-8b-stimulated myogenic cell proliferation is suppressed by the promyelocytic leukemia gene. Biological Signals and Receptors 10 285-293. (https://doi.org/10.1159/000046895)

Lammi J \& Aarnisalo P 2008 FGF-8 stimulates the expression of NR4A orphan nuclear receptors in osteoblasts. Molecular and Cellular Endocrinology 295 87-93. (https://doi.org/10.1016/j.mce.2008.08.023)

Leucht C, Stigloher C, Wizenmann A, Klafke R, Folchert A \& Bally-Cuif L 2008 MicroRNA-9 directs late organizer activity of the midbrainhindbrain boundary. Nature Neuroscience 11 641-648. (https://doi. org/10.1038/nn.2115)

Li Q, Kannan A, DeMayo FJ, Lydon JP, Cooke PS, Yamagishi H, Srivastava D, Bagchi MK \& Bagchi IC 2011 The antiproliferative action of progesterone in uterine epithelium is mediated by Hand2. Science 331912. (https://doi.org/10.1126/science.1197454)

Lima PF, Ormond CM, Caixeta ES, Barros RG, Price CA \& Buratini J 2016 Effect of kit ligand on natriuretic peptide precursor C and oocyte maturation in cattle. Reproduction 152 481-489. (https://doi. org/10.1530/REP-16-0155)

Lopez-Sanchez C, Franco D, Bonet F, Garcia-Lopez V, Aranega A \& Garcia-Martinez V 2015a Negative Fgf8-Bmp2 feed-back is regulated by miR-130 during early cardiac specification. Developmental Biology 406 63-73. (https://doi.org/10.1016/j.ydbio.2015.07.007)

Lopez-Sanchez C, Franco D, Bonet F, Garcia-Lopez V, Aranega A \& Garcia-Martinez V $2015 b$ Reciprocal repression between Fgf8 and miR133 regulates cardiac induction through Bmp2 signaling. Data in Brief $\mathbf{5}$ 59-64. (https://doi.org/10.1016/j.dib.2015.08.009)

Lorenzi MV, Long JE, Miki T \& Aaronson SA 1995 Expression cloning, developmental expression and chromosomal localisation of fibroblast growth factor 8. Oncogene 10 2051-2055.

Lutwak E, Price CA, Abramovich S-S, Rabinovitz S, Granot I, Dekel N \& Ron D 2014 Expression and regulation of the tumor suppressor, SEF, during folliculogenesis in humans and mice. Reproduction 148 507-517. (https://doi.org/10.1530/REP-14-0070)

MacArthur CA, Lawshe A, Xu J, Santos-Ocampo S, Heikinheimo M, Chellaiah AT \& Ornitz DM 1995a FGF-8 isoforms activate receptor splice forms that are expressed in mesenchymal regions of mouse development. Development 121 3603-3613.

MacArthur CA, Shankar DB \& Shackleford GM 1995b Fgf-8, activated by proviral insertion, cooperates with the Wnt-1 transgene in murine mammary tumorigenesis. Journal of Virology 69 2501-2507.

Machado MF, Portela VM, Price CA, Costa IB, Ripamonte P, Amorim RL \& Buratini J Jr 2009 Regulation and action of fibroblast growth factor 17 in bovine follicles. Journal of Endocrinology 202 347-353. (https://doi. org/10.1677/JOE-09-0145)

Machado MF, Caixeta ES, Sudiman J, Gilchrist RB, Thompson JG, Lima PF, Price CA \& Buratini J 2015 Fibroblast growth factor 17 and bone morphogenetic protein 15 enhance cumulus expansion and improve quality of in vitro-produced embryos in cattle. Theriogenology $\mathbf{8 4}$ 390-398. (https://doi.org/10.1016/j.theriogenology.2015.03.031)

Marmé F, Hielscher T, Hug S, Bondong S, Zeillinger R, Castillo-Tong DC, Sehouli J, Braicu I, Vergote I, Isabella C et al. 2012 Fibroblast growth factor receptor 4 gene (FGFR4) 388Arg allele predicts prolonged survival and platinum sensitivity in advanced ovarian cancer. International Journal of Cancer 131 E586-E591. (https://doi.org/10.1002/ijc.27329)

Masoumi-Moghaddam S, Amini A, Wei A-Q, Robertson G \& Morris DL 2015a Sprouty 1 predicts prognosis in human epithelial ovarian cancer. American Journal of Cancer Research 5 1531-1541.

Masoumi-Moghaddam S, Amini A, Wei A-Q, Robertson G \& Morris DL $2015 b$ Sprouty 2 protein, but not Sprouty 4 , is an independent prognostic biomarker for human epithelial ovarian cancer. International Journal of Cancer 137 560-570. (https://doi.org/10.1002/ijc.29425) 
Mattila MM \& Härkönen PL 2007 Role of fibroblast growth factor 8 in growth and progression of hormonal cancer. Cytokine and Growth Factor Reviews 18 257-266. (https://doi.org/10.1016/j.cytogfr.2007.04.010)

Meng QH, Xu E, Hildebrandt MAT, Liang D, Lu K, Ye Y, Wagar EA \& Wu X 2013 Genetic variants in the fibroblast growth factor pathway as potential markers of ovarian cancer risk, therapeutic response, and clinical outcome. Clinical Chemistry 60 222. (https://doi.org/10.1373/ clinchem.2013.211490)

Mishra SR, Thakur N, Somal A, Parmar MS, Reshma R, Rajesh G, Yadav VP, Bharti MK, Bharati J, Paul A et al. 2016 Expression and localization of fibroblast growth factor (FGF) family in buffalo ovarian follicle during different stages of development and modulatory role of FGF2 on steroidogenesis and survival of cultured buffalo granulosa cells. Research in Veterinary Science 108 98-111. (https://doi.org/10.1016/j. rvsc.2016.08.012)

Miyoshi T, Otsuka F, Yamashita M, Inagaki K, Nakamura E, Tsukamoto N, Takeda M, Suzuki J \& Makino H 2010 Functional relationship between fibroblast growth factor-8 and bone morphogenetic proteins in regulating steroidogenesis by rat granulosa cells. Molecular and Cellular Endocrinology 325 84-92. (https://doi.org/10.1016/j.mce.2010.04.012)

Miyoshi T, Otsuka F, Nakamura E, Inagaki K, Ogura-Ochi K, Tsukamoto N, Takeda M \& Makino H 2012 Regulatory role of kit ligand-c-kit interaction and oocyte factors in steroidogenesis by rat granulosa cells. Molecular and Cellular Endocrinology 358 18-26. (https://doi.org/10.1016/j. mce.2012.02.011)

Mustacchi G, Sormani PM, Bruzzi P, Gennari A, Zanconati F, Bonifacio D, Monzoni A \& Morandi L 2013 Identification and validation of a new se of five genes for prediction of risk in early breast cancer. International Journal of Molecular Sciences 14 9686-9702. (https://doi.org/10.3390/ ijms14059686)

Nadeau-Vallée M, Obari D, Palacios J, Brien M-È, Duval C, Chemtob S \& Girard S 2016 Sterile inflammation and pregnancy complications: a review. Reproduction 152 R277-R292. (https://doi.org/10.1530/REP-160453)

Nallasamy S, Li Q, Bagchi MK \& Bagchi IC 2012 Msx homeobox genes critically regulate embryo implantation by controlling paracrine signaling between uterine stroma and epithelium. PLOS Genetics 8 e1002500. (https://doi.org/10.1371/journal.pgen.1002500)

Ocón-Grove OM, Cooke FNT, Alvarez IM, Johnson SE, Ott TL \& Ealy AD 2008 Ovine endometrial expression of fibroblast growth factor (FGF) 2 and conceptus expression of FGF receptors during early pregnancy. Domestic Animal Endocrinology 34 135-145. (https://doi.org/10.1016/j. domaniend.2006.12.002)

Okumu LA, Forde N, Mamo S, McGettigan P, Mehta JP, Roche JF \& Lonergan P 2014 Temporal regulation of fibroblast growth factors and their receptors in the endometrium and conceptus during the preimplantation period of pregnancy in cattle. Reproduction 147 825-834. (https://doi.org/10.1530/REP-13-0373)

Olsen SK, Li JYH, Bromleigh C, Eliseenkova AV, Ibrahimi OA, Lao Z, Zhang F, Linhardt RJ, Joyner AL \& Mohammadi M 2006 Structural basis by which alternative splicing modulates the organizer activity of FGF8 in the brain. Genes and Development 20 185-198. (https://doi. org/10.1101/gad.1365406)

Ornitz DM \& Itoh N 2015 The fibroblast growth factor signaling pathway. Wiley Interdisciplinary Reviews: Developmental Biology 4 215-266. (https://doi.org/10.1002/wdev.176)

Ornitz DM, Xu J, Colvin JS, McEwen DG, MacArthur CA, Coulier F, Gao G \& Goldfarb M 1996 Receptor specificity of the fibroblast growth factor family. Journal of Biological Chemistry 271 15292-15297. (https://doi.org/10.1074/jbc.271.25.15292)

Peluso JJ, Pappalardo A \& Fernandez G 2001 Basic fibroblast growth factor maintains calcium homeostasis and granulosa cell viability by stimulating calcium efflux via a PKC delta-dependent pathway. Endocrinology 142 4203-4211. (https://doi.org/10.1210/endo.142.10.8460)

Pollock PM, Gartside MG, Dejeza LC, Powell MA, Mallon MA, Cancer Genome P, Davies H, Mohammadi M, Futreal PA, Stratton MR et al. 2007 Frequent activating FGFR2 mutations in endometrial carcinomas parallel germline mutations associated with craniosynostosis and skeletal dysplasia syndromes. Oncogene 26 7158-7162. (https://doi. org/10.1038/sj.onc.1210529)

Polnaszek N, Kwabi-Addo B, Wang J \& Ittmann M 2004 FGF17 is an autocrine prostatic epithelial growth factor and is upregulated in benign prostatic hyperplasia. Prostate 60 18-24. (https://doi.org/10.1002/ pros.20026)

Popovici C, Roubin R, Coulier F \& Birnbaum D 2005 An evolutionary history of the FGF superfamily. Bioessays 27 849-857. (https://doi. org/10.1002/bies.20261)

Portela VM, Machado M, Buratini J Jr, Zamberlam G, Amorim RL, Goncalves P \& Price CA 2010 Expression and function of fibroblast growth factor 18 in the ovarian follicle in cattle. Biology of Reproduction 83 339-346. (https://doi.org/10.1095/biolreprod.110.084277)

Portela VM, Dirandeh E, Guerrero-Netro HM, Zamberlam G, Barreta MH, Goetten AF \& Price CA 2015 The role of fibroblast growth factor-18 in follicular atresia in cattle. Biology of Reproduction 92 11-18.

Price CA 2016 Mechanisms of fibroblast growth factor signaling in the ovarian follicle. Journal of Endocrinology 228 R31-R43. (https://doi. org/10.1530/JOE-15-0414)

Puscheck EE, Patel Y \& Rappolee DA 1997 Fibroblast growth factor receptor (FGFR)-4, but not FGFR-3 is expressed in the pregnant ovary. Molecular and Cellular Endocrinology 132 169-176. (https://doi.org/10.1016/ S0303-7207(97)00131-7)

Robert C, Gagné D, Bousquet D, Barnes FL \& Sirard M-A 2001 Differential display and suppressive subtractive hybridization used to identify granulosa cell messenger RNA associated with bovine oocyte developmental competence. Biology of Reproduction 64 1812-1820. (https://doi.org/10.1095/biolreprod64.6.1812)

Sánchez F, Adriaenssens T, Romero S \& Smitz J 2010 Different folliclestimulating hormone exposure regimens during antral follicle growth alter gene expression in the cumulus-oocyte complex in mice. Biology of Reproduction 83 514-524. (https://doi.org/10.1095/ biolreprod.109.083311)

Sánchez F, Romero S \& Smitz J 2011 Oocyte and cumulus cell transcripts from cultured mouse follicles are induced to deviate from normal in vivo conditions by combinations of insulin, follicle-stimulating hormone, and human chorionic gonadotropin. Biology of Reproduction 85 565-574. (https://doi.org/10.1095/biolreprod.111.091744)

Santos-Biase WKF, Biase FH, Buratini J, Balieiro J, Watanabe YF, Accorsi MF, Ferreira CR, Stranieri P, Caetano AR \& Meirelles FV 2012 Single nucleotide polymorphisms in the bovine genome are associated with the number of oocytes collected during ovum pick up. Animal Reproduction Science 134 141-149. (https://doi.org/10.1016/j. anireprosci.2012.08.017)

Satterfield MC, Hayashi K, Song G, Black SG, Bazer FW \& Spencer TE 2008 Progesterone regulates FGF10, MET, IGFBP1, and IGFBP3 in the endometrium of the ovine uterus. Biology of Reproduction 79 1226-1236. (https://doi.org/10.1095/biolreprod.108.071787)

Schams D, Steinberg V, Steffl M, Meyer HHD \& Berisha B 2009 Expression and possible role of fibroblast growth factor family members in porcine antral follicles during final maturation. Reproduction 138 141-149. (https://doi.org/10.1530/REP-09-0033)

Schmitt JF, Hearn MT \& Risbridger GP 1996 Expression of fibroblast growth factor-8 in adult rat tissues and human prostate carcinoma cells. Journal of Steroid Biochemistry and Molecular Biology 57 173-178. (https://doi. org/10.1016/0960-0760(95)00259-6)

Steele IA, Edmondson RJ, Bulmer JN, Bolger BS, Leung HY \& Davies BR 2001 Induction of FGF receptor 2-IIlb expression and response to its ligands in epithelial ovarian cancer. Oncogene 20 5878-5887. (https://doi.org/10.1038/sj.onc.1204755)

Sugiura K, Su Y-Q, Diaz FJ, Pangas SA, Sharma S, Wigglesworth K, O'Brien MJ, Matzuk MM, Shimasaki S \& Eppig JJ 2007 Oocyte-derived BMP15 and FGFs cooperate to promote glycolysis in cumulus cells. Development 134 2593-2603. (https://doi.org/10.1242/dev.006882)

Sugiura K, Su YQ, Li Q, Wigglesworth K, Matzuk MM \& Eppig JJ 2009 Fibroblast growth factors and epidermal growth factor cooperate with oocyte-derived members of the TGFbeta superfamily to regulate Spry2 mRNA levels in mouse cumulus cells. Biology of Reproduction $\mathbf{8 1}$ 833-841. (https://doi.org/10.1095/biolreprod.109.078485)

Tanaka A, Miyamoto K, Minamino N, Takeda M, Sato B, Matsuo H \& Matsumoto K 1992 Cloning and characterization of an androgeninduced growth factor essential for the androgen-dependent growth of mouse mammary carcinoma cells. PNAS 89 8928-8932. (https://doi. org/10.1073/pnas.89.19.8928)

Tanaka A, Kamiakito T, Hakamata Y, Fujii A, Kuriki K \& Fukayama M 2001 Extensive neuronal localization and neurotrophic function of fibroblast 
growth factor 8 in the nervous system. Brain Research 912 105-115. (https://doi.org/10.1016/S0006-8993(01)02726-3)

Trudel C, Faure-Desire V, Florkiewicz RZ \& Baird A 2000 Translocation of FGF2 to the cell surface without release into conditioned media. Journal of Cellular Physiology 185 260-268. (https://doi.org/10.1002/10974652(200011)185:2<260::AID-JCP11>3.0.CO;2-X)

Valve E, Penttila TL, Paranko J \& Harkonen P 1997 FGF-8 is expressed during specific phases of rodent oocyte and spermatogonium development. Biochemical and Biophysical Research Communications 232 173-177. (https://doi.org/10.1006/bbrc.1997.6256)

Valve E, Martikainen P, Seppanen J, Oksjoki S, Hinkka S, Anttila L, Grenman S, Klemi P \& Harkonen P 2000 Expression of fibroblast growth factor (FGF)-8 isoforms and FGF receptors in human ovarian tumors. International Journal of Cancer 88 718-725. (https://doi. org/10.1002/1097-0215(20001201)88:5<718::AID-IJC6>3.0.CO;2-F)

Vathipadiekal V, Wang V, Wei W, Waldron L, Drapkin R, Gillette M, Skates S \& Birrer M 2015 Creation of a human secretome: a novel composite library of human secreted proteins: validation using ovarian cancer gene expression data and a virtual secretome array. Clinical Cancer Research 21 4960. (https://doi.org/10.1158/1078-0432.CCR-14-3173)

Velasco A, Pallares J, Santacana M, Gatius S, Fernandez M, Domingo M, Valls J, Yeramian A, Encinas M, Dolcet X et al. 2011 Promoter hypermethylation and expression of sprouty 2 in endometrial carcinoma. Human Pathology 42 185-193. (https://doi.org/10.1016/j. humpath.2010.08.001)

Vernon RK \& Spicer LJ 1994 Effects of basic fibroblast growth factor and heparin on follicle-stimulating hormone-induced steroidogenesis by bovine granulosa cells. Journal of Animal Science 72 2696-2702. (https://doi.org/10.2527/1994.72102696x)

Wang Y, Yang T, Liu Y, Zhao W, Zhang Z, Lu M \& Zhang W 2017 Decrease of miR-195 promotes chondrocytes proliferation and maintenance of chondrogenic phenotype via targeting FGF-18 pathway. International Journal of Molecular Sciences 18 E975. (https://doi.org/10.3390/ ijms18050975)

Wei W, Mok SC, Oliva E, Kim S-h, Mohapatra G \& Birrer MJ 2013 FGF18 as a prognostic and therapeutic biomarker in ovarian cancer. Journal of Clinical Investigation 123 4435-4448. (https://doi.org/10.1172/ JCI70625)

Welter H, Wollenhaupt K \& Einspanier R 2004 Developmental and hormonal regulated gene expression of fibroblast growth factor 2 (FGF-2) and its receptors in porcine endometrium. Journal of Steroid Biochemistry and Molecular Biology 88 295-304. (https://doi. org/10.1016/j.jsbmb.2003.12.011)

Wollenhaupt K, Welter H, Einspanier R, Manabe N \& Brüssow K-P 2004 Expression of epidermal growth factor receptor (EGF-R), vascular endothelial growth factor receptor (VEGF-R) and fibroblast growth factor receptor (FGF-R) systems in porcine oviduct and endometrium during the time of implantation. Journal of Reproduction and Development $\mathbf{5 0}$ 269-278. (https://doi.org/10.1262/jrd.50.269)

Yang Q, Jia C, Wang P, Xiong M, Cui J, Li L, Wang W, Wu Q, Chen Y \& Zhang T 2014 MicroRNA-505 identified from patients with essential hypertension impairs endothelial cell migration and tube formation. International Journal of Cardiology 177 925-934. (https://doi. org/10.1016/j.ijcard.2014.09.204)

Yerlikaya G, Balendran S, Pröstling K, Reischer T, Birner P, Wenzl R, Kuessel L, Streubel B \& Husslein H 2016 Comprehensive study of angiogenic factors in women with endometriosis compared to women without endometriosis. European Journal of Obstetrics and Gynecology and Reproductive Biology 204 88-98. (https://doi.org/10.1016/j. ejogrb.2016.07.500)

Yu K, Herr AB, Waksman G \& Ornitz DM 2000 Loss of fibroblast growth factor receptor 2 ligand-binding specificity in Apert syndrome. PNAS $\mathbf{9 7}$ 14536-14541. (https://doi.org/10.1073/pnas.97.26.14536)

Zaid TM, Yeung T-L, Thompson MS, Leung CS, Harding T, Co N-N, Schmandt RS, Kwan S-Y, Rodriguez-Aguay C, Lopez-Berestein G et al. 2013 Identification of FGFR4 as a potential therapeutic target for advanced-stage, high-grade serous ovarian cancer. Clinical Cancer Research 19 809. (https://doi.org/10.1158/1078-0432.CCR-12-2736)

Zammit C, Coope R, Gomm JJ, Shousha S, Johnston CL \& Coombes RC 2002 Fibroblast growth factor 8 is expressed at higher levels in lactating human breast and in breast cancer. British Journal of Cancer $\mathbf{8 6}$ 1097-1103. (https://doi.org/10.1038/sj.bjc.6600213)

Zhang X, Ibrahimi OA, Olsen SK, Umemori H, Mohammadi M \& Ornitz DM 2006 Receptor specificity of the fibroblast growth factor family. The complete mammalian FGF family. Journal of Biological Chemistry 281 15694-15700. (https://doi.org/10.1074/jbc.M601252200)

Zhong W, Wang QT, Sun T, Wang F, Liu J, Leach R, Johnson A, Puscheck EE \& Rappolee DA 2006 FGF ligand family mRNA expression profile for mouse preimplantation embryos, early gestation human placenta, and mouse trophoblast stem cells. Molecular Reproduction and Development 73 540-550. (https://doi.org/10.1002/mrd.20417)

Zisman-Rozen S, Fink D, Ben-Izhak O, Fuchs Y, Brodski A, Kraus MH, Bejar J \& Ron D 2007 Downregulation of Sef, an inhibitor of receptor tyrosine kinase signaling, is common to a variety of human carcinomas. Oncogene 26 6093-6098. (https://doi.org/10.1038/sj.onc.1210424)

Received 31 August 2017

First decision 28 September 2017

Revised manuscript received 12 October 2017

Accepted 6 November 2017 